\title{
Evaluation of the Shelf Life of Packaged Roast Beef and Some Treatments for Its Extension
}

\author{
Tamador Maayah"1, Malak Angor ${ }^{2 *}$, Khaled Al-Marazeeq ${ }^{2}$, Basem Al-Abdullah ${ }^{3}$ \\ ${ }^{1}$ Risk Management Unit at Jordan Food and Drug Administration, Amman, Jordan \\ ${ }^{2}$ Al-Huson University College, Al-Balqa Applied University, Al-Huson, Jordan \\ ${ }^{3}$ Faculty of Agriculture, University of Jordan, Amman, Jordan \\ Email:Tamador.maayah@jfda.jo, ${ }^{*}$ dr.angormalak@bau.edu.jo,Basem@ju.edu.jo
}

Received 23 February 2016; accepted 27 March 2016; published 30 March 2016

Copyright (C) 2016 by authors and Scientific Research Publishing Inc.

This work is licensed under the Creative Commons Attribution International License (CC BY). http://creativecommons.org/licenses/by/4.0/

(c) () D Den Access

\begin{abstract}
This study was carried out to investigate the effect of nitrite concentration, and abused chilling temperature against proper chilling temperature on the chemical, microbiological and shelf life of roast beef stored at $4^{\circ} \mathrm{C}$ and $12^{\circ} \mathrm{C}$. Three roast beef treatments were formulated to investigate the effect of nitrite concentration $(0.006 \%, 0.012 \%$ and $0.018 \%)$ and abused chilling temperature $\left(12^{\circ} \mathrm{C}\right)$ against control treatment $\left(0.026 \%\right.$ nitrite and storage at $\left.4^{\circ} \mathrm{C}\right)$ on the chemical, microbiological and shelf life. Results showed that roast beef containing $0.026 \%$ nitrite and stored at $4^{\circ} \mathrm{C}$ for 25 days had the lowest thiobarbituric acid (TBA) value while the highest TBA values were in the treatment containing $0.006 \%$ added nitrite, stored at $12^{\circ} \mathrm{C}$. The aerobic plate count, Enterobacteriaceae, lactic acid bacteria (LAB), and spore former count were increased throughout the storage period which was lower in $0.026 \%$ and $0.018 \%$ containing nitrite treatments while higher in other two treatments. The lowest percentage of nitrite losses during storage was in the samples having $0.026 \%$ added nitrite to roast beef. The results emphasized the risk of abused temperature and the importance of keeping this product under efficient and consistent refrigeration during storage and the use of high nitrite concentration to protect it and elongate its shelf life.
\end{abstract}

\section{Keywords}

Roasted Beef, Nitrite, Chilling Temperature, Shelf Life

\section{Introduction}

Roast beef is a cured, cooked, smoked whole meat piece product. It is usually consumed or served cold after *Corresponding author.

How to cite this paper: Maayah, T., Angor, M., Al-Marazeeq, K. and Al-Abdullah, B. (2016) Evaluation of the Shelf Life of Packaged Roast Beef and Some Treatments for Its Extension. Food and Nutrition Sciences, 7, 205-213.

http://dx.doi.org/10.4236/fns.2016.73022 
processing. As roast beef is a cured meat product, curing contributes a characteristic pink color, specific texture and flavor, and provides a preservative effect especially against the growth of spores of Clostridium botulinum [1] [2]. Nitrite is a critical component used to cure meat [3] [4].

Curing is accomplished by adding mixtures of salt, nitrite, spices and usually a reducing agent such as ascorbate, to meat. A heating step is usually employed some time after the curing process begins as in the case of roast beef [5]. In a series of normal reactions, nitrite is converted to nitric oxide. Nitric oxide combines with myoglobin, which is a deep red color that changes to the characteristic bright pink normally associated with cured and smoked meat when heated during the smoking process [6].

The observation that the added nitrite decreases rapidly during the curing process leaves no doubt that it is reacting with the components of meat and its role in the curing process is multifunctional [7]. Nitrite reacts with myoglobin to give nitrosylmyoglobin which is the pigment formed in cured meats [8]. Most meat products change progressively during storage, and the changes in most cases render them less attractive and palatable and eventually unfit for consumption.

Shelf life determination of a new product often requires storage for significant periods, and includes samples from early development stages as well as initial production runs. Through the evaluation of stored samples, potential storage problems can be identified and, either eliminated or controlled before the food goes into production. In production, an on-going quality assurance system is equally important, and involves assessment of freshly made products, typically before the production has been released into distribution. Samples stored for up to the assigned shelf life should also be evaluated, so that any change in the storage performance can be noted, and appropriate actions taken if necessary [9].

To keep meat products safe through the food chain is of great importance. Sodium nitrite is most commonly used in meat curing to help develop a desirable flavor and attractive color. Nitrite retards the development of meat rancidity and unpleasant flavors and odors of meat during storage. Moreover, it is a very effective inhibitor against the growth of spoilage and pathogenic microorganisms [3].

The objectives of this study were to:

- Evaluate the effect of nitrite concentration and the chilling temperature on the shelf life of roast beef (ready to eat).

- Determine the shelf life of roast beef under the selected conditions (nitrite level and chilling temperature).

- Evaluate the shelf life of roast beef obtained from the producer.

- Determine the effect of nitrite concentration within the storage chill temperature on the microbiological and oxidative rancidity of the studied roast beef.

\section{Materials and Methods}

\subsection{Roast Beef Manufacture}

Frozen raw beef topside was taken out of the freezer and tempered overnight. The meat blocks were cut into pieces of $10 \mathrm{~kg}$. It was then transferred to the brine injector where the injector delivers a solution of salt, sodium nitrite, potato starch, isolated soy bean protein, sodium ascorbate, sodium tri-poly phosphates, spices and water (Table 1).

The mixture was cooled to a temperature of $4^{\circ} \mathrm{C}$. The protein improves at cold temperatures, so we cool down the pipes that lead from the mix to the injector. After injection, the beef were transferred to the tumbler, which is also cooled down to $4^{\circ} \mathrm{C}$. The tumbling process takes about one hour under vacuum pressure. Then, the meat pieces were placed into fibrous packages, and the packaging process took place under vacuum, and was controlled by computer, each bag contained $1 \mathrm{~kg}$ of meat. The beef, then, was held for certain time at about $6^{\circ} \mathrm{C}$ $7^{\circ} \mathrm{C}[10]-[12]$.

\subsection{Cooking and Storage}

Roast beef batches were thermally processed in a steam oven as follows:

The beef in their special fibrous bags was dried for 40 minutes to lower the amount of water. Following drying the beef was liquid smoked at $76^{\circ} \mathrm{C}$; smoking took 1.30 hour, after smoking the beef was dried for 3 minutes. The roast beef was cooked to a core temperature of $74^{\circ} \mathrm{C}$ for 4 hours. After cooking the beef was allowed to dry to get a good color. Then the beef was taken out to be cool in the blasted chiller for four hours, to cool from 
Table 1. Meat and brine formula used to produce roast beef.

\begin{tabular}{|ccccc}
\hline & & \multicolumn{3}{c}{ Treatments } \\
Ingredients & A & B & C & D \\
\cline { 2 - 5 } Meat (kg) & 10 & 10 & 10 & 10 \\
Water (L) & 7 & 7 & 7 & 7 \\
Salt (\%) & 7 & 7 & 7 & 7 \\
Sodium tripolyphosphate (\%) & 2 & 2 & 2 & 0.3 \\
Sodium ascorbate (\%) & 0.3 & 0.3 & 0.3 & 0.026 \\
Sodium nitrite \% & 0.006 & 0.012 & 5 & 5 \\
Potato starch (\%) & 5 & 5 & 6 & 6 \\
Soybean isolate (\%) & 6 & 6 & 0.9 & 0.9 \\
Spices (\%) & 0.9 & 0.9 & 17 & 17 \\
Total (kg) & 17 & 17 & 5 \\
\hline
\end{tabular}

$64^{\circ} \mathrm{C}$ to $1^{\circ} \mathrm{C}$. After that, the roast beef was kept in refrigerator at $4^{\circ} \mathrm{C}$ throughout the duration of the experiment D. B, C and A samples from were taken to be kept at abused temperature $\left(12^{\circ} \mathrm{C}\right)$ (Table 2$)$.

\subsection{Chemical Measurements}

\subsubsection{Proximate Analysis}

Moisture, fat and protein were determined directly after storage using Infratech Analyzer (Model Tecator 1265, Sweden) [13]. Ash determination was carried out according to AOAC [14].

\subsection{2. $\mathrm{pH}$}

The roast beef pH was measured using pH meter (Model WPA, Cambridge) [15]. Two readings were obtained for each roast beef treatment.

\subsubsection{Total Meat Oxidation Testing (TBA)}

The extent of lipid oxidation was determined by the TBA method [16]. TBA was determined at 0, 4, 7, 19, 22, and 25 days during storage at $4^{\circ} \mathrm{C}$ and $12^{\circ} \mathrm{C}$. The TBA number was expressed as milligrams of malondaldehyde per kilogram of sample using a conversion factor of 7.8 [17].

\subsubsection{Nitrite Residue}

Nitrite residue was determined in duplicate sample for each treatment according to the colorimetric method of AOAC, method number 973.31 [14]. The absorbance was measured using UV/Visible spectrophotometer (Elico, SL 150, India) at $538 \mathrm{~nm}$.

\subsection{Microbiological Examinations}

Number of colony forming units (CFU) of the following microorganisms was counted [18] at 0, 4, 7, 19, 22, and 25 days during storage at $4^{\circ} \mathrm{C}$ and $12^{\circ} \mathrm{C}$ :

\subsubsection{Aerobic Plate Count (APC)}

A pour plate method of plate count agar (Hi Media, Bombay, India). Incubation was carried out at $30^{\circ} \mathrm{C}$ for 48 hours.

\subsubsection{Lactic Acid Bacteria}

Count was determined on pour plates of lactobacillus deManRogosa (MRS) agar (Hi Media, Bombay, India); incubation at $20^{\circ} \mathrm{C}-22^{\circ} \mathrm{C}$ for 48 hours. After counting all colonies that grow on the medium as presumptive positive lactic acid bacteria, smears of typical colonies were prepared for Gram stain, catalase test, and oxidase test. 
Table 2. Roast beef treatments.

\begin{tabular}{ccccc}
\hline Treatments & A & B & C & D \\
\hline Cooking temperature $\left({ }^{\circ} \mathbf{C}\right)$ & 75 & 75 & 75 & 75 \\
Chilling storage temperature $\left({ }^{\circ} \mathbf{C}\right)$ & 12 & 12 & 12 & 4 \\
\hline
\end{tabular}

\subsubsection{Enterobacteriaceae Count}

This count was determined using pour plate method of violet red bile glucose agar (Scharlau Chemie, Spain). Incubation was carried out at $37^{\circ} \mathrm{C}$ for 24 hours. Then the oxidase test and the oxidation fermentation test (OF) were carried out (ICMSF, 1978).

\subsubsection{Anaerobic Spore Formers}

Was determined using a poured plate method of reinforced Clostridia agar (Hi Media, Bombay, India). Incubation was carried out anaerobically at $35^{\circ} \mathrm{C}-37^{\circ} \mathrm{C}$ for 20 hours.

\subsection{Statistical Analysis}

Statistical analysis of data was carried out using Statistical Analysis System (SAS) package. Analysis of variance (ANOVA) of the general linear models (GLM) procedure of statistical analysis system. The significant differences between means were determined at $\mathrm{p}<0.05$ using Duncan Multiple Range Test [19] [20].

\section{Results and Discussion}

\subsection{Proximate Analysis and $\mathrm{pH}$}

Proximate contents of the roast beef were $78.4 \%$ moisture, $1.8 \%$ fat, $14.8 \%$ protein, and $3 \%$ ash.

The $\mathrm{pH}$ value of all products was found to be 6.2 which can be expected to be relatively high, attributable to addition of sodium polyphosphate [21]. In addition, heating to $76^{\circ} \mathrm{C}$ was sufficient to destroy vegetative cells of pathogens, but was insufficient to destroy aerobic spore formers present in meat which could be responsible for the increased $\mathrm{pH}$ of roast beef [18] [22].

\subsection{Nitrite Residues}

The results of the residual nitrite are shown in Table 3. As shown from this table residual nitrite in treatment $\mathrm{D}$ was significantly higher when compared with treatment A, B and C. It was observed that the more sodium nitrite is added, the more it will be involved in the reactions.

The percent of nitrite losses increased with time. Losses in treatments $\mathrm{A}, \mathrm{B}$, and $\mathrm{C}$ were about $89 \%$ during storage period at $12^{\circ} \mathrm{C}$, whereas treatment $\mathrm{D}$ which had $0.026 \%$ added nitrite during storage period at $4^{\circ} \mathrm{C}$ showed $81 \%$ of nitrite losses. Higher sodium nitrite concentration, more reactions will occur with meat components especially protein, but there is a limit for protein to react with nitrite, so protein reached the saturation level that means no more protein to react with nitrite.

When nitrite is added to the biologically complex system of meat, it reacts with or is bound to various naturally occurring chemical components such as protein. The heating conditions normally used in the curing process speeds up these reactions, and when the manufacturing process is complete, only about $10 \%-20 \%$ of the originally added nitrite is analytically detectable. These so-called residual nitrite level declines further during storage and distribution, as the product moves to the consumer for final preparation and consumption [4] [23]. These results show the importance of the storage temperature in determining nitrite losses which affect the shelf life of the roast beef.

\subsection{Oxidative Rancidity Test}

TBA values for the stored roast beef which were measured on days $0,4,7,19,22$, and 25 following storage at $4^{\circ} \mathrm{C}$ and $12^{\circ} \mathrm{C}$ are presented in Table 4 . The TBA values of all roast beef treatments at start of storage was low as found in previous studies done on cured meat products [24]. TBA values were doubled after four days and further increased throughout storage period, where they reached a maximum value of $1.13 \mathrm{mg} / \mathrm{kg}$ for treatment 
Table 3. Residual nitrite levels of stored roast beef at different storage times.

\begin{tabular}{|c|c|c|c|c|}
\hline \multirow[b]{2}{*}{ Storage time (days) } & \multicolumn{4}{|c|}{ Treatments } \\
\hline & $\begin{array}{c}\mathrm{A} \\
\left(12^{\circ} \mathrm{C}, 0.006 \%\right)\end{array}$ & $\begin{array}{c}\text { B } \\
\left(12^{\circ} \mathrm{C}, 0.012 \%\right)\end{array}$ & $\begin{array}{c}\mathrm{C} \\
\left(12^{\circ} \mathrm{C}, \mathbf{0 . 0 1 8 \%}\right)\end{array}$ & $\begin{array}{c}\text { D } \\
\left(12^{\circ} \mathrm{C}, 0.026 \%\right)\end{array}$ \\
\hline $\mathbf{0}$ & 18.2 & 36.5 & 55.4 & 80.6 \\
\hline 4 & 14.6 & 29.8 & 45 & 75.4 \\
\hline 7 & 12.2 & 25.2 & 38.3 & 71.0 \\
\hline 19 & 9.3 & 19.1 & 29 & 61.4 \\
\hline 22 & 7.8 & 15.7 & 24 & 52.5 \\
\hline 25 & 6.2 & 12.4 & 19.6 & 49.4 \\
\hline
\end{tabular}

Table 4. TBA values of stored roast beef.

\begin{tabular}{|c|c|c|c|c|}
\hline \multirow[b]{2}{*}{ Storage time (days) } & \multicolumn{4}{|c|}{ Treatments } \\
\hline & $\begin{array}{c}\mathrm{A} \\
\left(12^{\circ} \mathrm{C}, 0.006 \%\right)\end{array}$ & $\begin{array}{c}\mathrm{B} \\
\left(12^{\circ} \mathrm{C}, 0.012 \%\right)\end{array}$ & $\begin{array}{c}\mathrm{C} \\
\left(12^{\circ} \mathrm{C}, 0.018 \%\right)\end{array}$ & $\begin{array}{c}\text { D } \\
\left(12^{\circ} \mathrm{C}, 0.026 \%\right)\end{array}$ \\
\hline $\mathbf{0}$ & 0.40 & 0.23 & 0.16 & 0.10 \\
\hline 4 & 0.60 & 0.42 & 0.30 & 0.13 \\
\hline 7 & 0.90 & 0.80 & 0.60 & 0.24 \\
\hline 19 & 1.10 & 0.95 & 0.82 & 0.36 \\
\hline 22 & 1.30 & 1.10 & 0.98 & 0.42 \\
\hline 25 & 1.50 & 1.30 & 1.13 & 0.53 \\
\hline
\end{tabular}

C, $1.3 \mathrm{mg} / \mathrm{kg}$ for treatment B and $1.5 \mathrm{mg} / \mathrm{kg}$ for treatment A. In contrast treatment D (0.026\% nitrite) did not exceed $0.53 \mathrm{mg} / \mathrm{kg}$.

Nitrite is known to have antioxidant effect in cured meat products [25] [26], but the level needed to get antioxidative effects was unknown. Nitrite or dinitrogen trioxide reacts with unsaturated lipids to form nitro-nitroso derivatives, thus stabilizing the lipids toward peroxidation changes. This mechanism can, in part, explain the antioxidation role of nitrite in cured meats [27] [28].

From these results we can conclude that $0.026 \%$ and $0.0180 \%$ nitrite have a better antioxidant effect than $0.012 \%$ and $0.006 \%$ level at the initial and during storage. Moreover, TBA values for abused treatments were higher than refrigerated treatment, so the chemical deterioration is supposed to be faster.

Lipid oxidation of muscle foods results in formation of harmful products like malondialdehyde, degradation of fatty acids, carcinogenesis and formation of metmyglobin in meat products. Moreover, protein oxidation accelerated by free radicals decrease the nutritional value of meat due to loss of essential amino acids and low digestibility of oxidized proteins [29].

\subsection{Microbiological Analysis of Roast Beef}

The effects of various preservative combinations upon microbial growth were studied during different storage times. All results are average values of duplicate samples from four treatments and were expressed as $\log _{10}$ $\mathrm{CFU} / \mathrm{g}$ (colony forming units/g).

\subsubsection{Aerobic Plate Count}

Table 5 shows the APC values for all treatments at different storage time. As expected bacterial loads expressed as APC increased considerably during storage. The results demonstrate the importance of storage temperature in determining APC counts that reflects the shelf life of roast beef.

However, the APC counts are considered fairly satisfactory when colony counts is 3 - $5 \log _{10} \mathrm{CFU} / \mathrm{g}$, and unsatisfactory when they reached more than $6 \log _{10} \mathrm{CFU} / \mathrm{g}$ [30]-[32]. The APC counts did not reach the unsatisfactory limit in $0.026 \%$ and $0.018 \%$ nitrite roast beef, even at the end of the tested storage period, whereas in 
Table 5. APC as means value of $\log _{10} \mathrm{CFU} / \mathrm{g}$ for all treatment at different storage time.

\begin{tabular}{|c|c|c|c|c|c|c|}
\hline \multirow{2}{*}{ Treatments } & \multicolumn{6}{|c|}{ Storage time (Days) } \\
\hline & $\mathbf{0}$ & 4 & 7 & 19 & 22 & 25 \\
\hline $\begin{array}{c}\mathrm{A} \\
\left(12^{\circ} \mathrm{C}, 0.006 \%\right)\end{array}$ & 3.12 & 3.42 & 5.49 & 7.20 & 7.30 & 7.57 \\
\hline $\begin{array}{c}\text { B } \\
\left(12^{\circ} \mathrm{C}, 0.012 \%\right)\end{array}$ & 2.75 & 3.16 & 4.96 & 6.37 & 6.48 & 6.59 \\
\hline $\begin{array}{c}\mathrm{C} \\
\left(12^{\circ} \mathrm{C}, 0.018 \%\right)\end{array}$ & 2.30 & 2.91 & 4.53 & 5.51 & 5.57 & 5.68 \\
\hline $\begin{array}{c}\text { D } \\
\left(12^{\circ} \mathrm{C}, 0.026 \%\right)\end{array}$ & 2.00 & 2.35 & 2.39 & 3.61 & 3.62 & 4.00 \\
\hline
\end{tabular}

treatment $0.012 \%$ and $0.006 \%$ nitrite roast beef have reached this limit at day 19 , indicating that treatment $\mathrm{D}$ would be spoiled later after all the other treatments which mean longer shelf life. This means that the increase in APC counts affects the shelf life of the roast beef, also the storage temperature is important to extend the shelf life of the roast beef.

\subsubsection{Lactic Acid Bacteria}

Table 6 represents the lactic acid bacteria (LAB) counts of the stored roast beef. Treatment D had significantly $(\mathrm{P}<0.05)$ lower lactic acid bacteria $(\mathrm{LAB})$ counts $(1.37)$ in comparison with the other treatments. It has been found that treatment $\mathrm{A}$, which had $0.006 \%$ added nitrite to the roast beef, had a significantly $(\mathrm{P}<0.05)$ higher lactic acid bacteria (LAB) counts (3.16). These results show the importance of storage temperature in determining lactic acid bacteria (LAB) values which affect the shelf life of roast beef, and this indicates the strong inhibitory effects of nitrite against lactic acid bacteria (LAB).

Lactic acid bacteria are the most frequently isolated bacteria from this kind of meat products (roast beef) since they are tolerant to $\mathrm{CO}_{2}$ and low temperature. The adoption of modified atmospheres or vacuum for the packaging of roast beef has shown that lactic acid bacteria generally become numerically dominant in such environments [33]-[36].

\subsubsection{Enterobacteriaceae}

Table 7 represents the Entembacteriaceae counts of the stored roast beef. Treatments D and C had significantly $(\mathrm{P}<0.05)$ lower Enterabacteriacea counts (2.99 and 3.19 respectively) in comparison with the other treatments. This slight growth inhibition effect could be attributed to the presence of higher nitrite level .It has been found that treatments B and A, which had $0.012 \%$ and $0.006 \%$ added nitrite respectively, had a significantly $(\mathrm{P}<0.05)$ higher Enterobacteriaceae counts (3.61 and 3.64 respectively); this antimicrobial effect could be attributed to the presence of lower nitrite level and abuse storage temperature.

These results show the importance of storage temperature in determining Enterobacteriaceae counts which has a direct influence on the product shelf life.

Nitrite has a proven bacteriostatic effect on Enterobacteria [37]. The counts were considered unsatisfactory when reached more than 3 logic CFU/g [32]. At the end of the storage period $0.018 \%, 0.012 \%$ and $0.006 \%$ added nitrite to roast beef have reached this limit at day 7 , so it is the end of its shelf life, and reached this limit at day 22 for $0.026 \%$ added nitrite to roast beef, indicating that treatment D spoiled 2 weeks after all the other treatment which means longer shelf life than the others. So the end of shelf life of roast beef reached at 7 days in treatments A, B, C, depending on the count of Enterobacteriaceae, whereas treatment D reached the end of its shelf life at 22 days.

\subsubsection{Anaerobic Spore Formers}

Table 8 represents the anaerobic spore formers counts of the stored roast beef. Treatment D had significantly $(\mathrm{P}<0.05)$ lower anaerobic spore formers counts $(1.07)$ in comparison with the other treatments. It has been found that treatment $\mathrm{A}$, with $0.006 \%$ added nitrite, had a significantly $(\mathrm{P}<0.05)$ higher anaerobic spore formers count (5.47), while treatments B and C were between them. $0.026 \%$ nitrite level had the lowest anaerobic spore formers count, nitrite has a proven particularly lethal effect on anaerobic spore formers [37]. The increase in 
Table 6. Lactic acid bacteria as means value of $\log _{10} \mathrm{CFU} / \mathrm{g}$ for all treatment at different storage time.

\begin{tabular}{|c|c|c|c|c|c|c|}
\hline \multirow{2}{*}{ Treatments } & \multicolumn{6}{|c|}{ Storage time (Days) } \\
\hline & $\mathbf{0}$ & 4 & 7 & 19 & 22 & 25 \\
\hline $\begin{array}{c}A \\
\left(12^{\circ} \mathrm{C}, 0.006 \%\right)\end{array}$ & 2.24 & 2.82 & 3.05 & 3.17 & 3.26 & 3.45 \\
\hline $\begin{array}{c}\text { B } \\
\left(12^{\circ} \mathrm{C}, 0.012 \%\right)\end{array}$ & 2.04 & 2.69 & 2.77 & 3.07 & 3.15 & 3.29 \\
\hline $\begin{array}{c}\mathrm{C} \\
\left(12^{\circ} \mathrm{C}, \mathrm{0.018 \%}\right)\end{array}$ & 1.69 & 2.11 & 2.37 & 2.59 & 2.81 & 3.03 \\
\hline $\begin{array}{c}\text { D } \\
\left(12^{\circ} \mathrm{C}, 0.026 \%\right)\end{array}$ & 1.00 & 1.39 & 1.48 & 1.54 & 1.72 & 1.81 \\
\hline
\end{tabular}

Table 7. Enterobacteriaceae as means value of $\log _{10} \mathrm{CFU} / \mathrm{g}$ for all treatment at different storage time.

\begin{tabular}{|c|c|c|c|c|c|c|}
\hline \multirow{2}{*}{ Treatments } & \multicolumn{6}{|c|}{ Storage time (Days) } \\
\hline & $\mathbf{0}$ & 4 & 7 & 19 & 22 & 25 \\
\hline $\begin{array}{c}\mathrm{A} \\
\left(12^{\circ} \mathrm{C}, 0.006 \%\right)\end{array}$ & 2.13 & 2.98 & 3.42 & 3.42 & 4.09 & 4.12 \\
\hline $\begin{array}{c}\text { B } \\
\left(12^{\circ} \mathrm{C}, 0.012 \%\right)\end{array}$ & 2.06 & 2.79 & 3.35 & 3.37 & 4.08 & 4.09 \\
\hline $\begin{array}{c}\mathrm{C} \\
\left(12^{\circ} \mathrm{C}, 0.018 \%\right)\end{array}$ & 1.48 & 2.67 & 3.25 & 3.30 & 3.72 & 3.76 \\
\hline $\begin{array}{c}\mathrm{D} \\
\left(12^{\circ} \mathrm{C}, 0.026 \%\right)\end{array}$ & 1.00 & 2.48 & 2.79 & 2.89 & 3.43 & 3.57 \\
\hline
\end{tabular}

Table 8. Anaerobic spore formers as means value of $\log _{10} \mathrm{CFU} / \mathrm{g}$ for all treatment at different storage time.

\begin{tabular}{|c|c|c|c|c|c|c|}
\hline \multirow{2}{*}{ Treatments } & \multicolumn{6}{|c|}{ Storage time (Days) } \\
\hline & $\mathbf{0}$ & 4 & 7 & 19 & 22 & 25 \\
\hline $\begin{array}{c}A \\
\left(12^{\circ} \mathrm{C}, 0.006 \%\right)\end{array}$ & 2.44 & 2.82 & 3.04 & 5.39 & 5.72 & 5.93 \\
\hline $\begin{array}{c}B \\
\left(12^{\circ} \mathrm{C}, 0.012 \%\right)\end{array}$ & 1.95 & 2.51 & 2.85 & 5.30 & 5.65 & 5.65 \\
\hline $\begin{array}{c}\mathrm{C} \\
\left(12^{\circ} \mathrm{C}, 0.018 \%\right)\end{array}$ & 1.69 & 2.24 & 2.47 & 4.51 & 4.79 & 5.52 \\
\hline $\begin{array}{c}\text { D } \\
\left(12^{\circ} \mathrm{C}, 0.026 \%\right)\end{array}$ & $<1$ & 1.00 & 1.56 & 1.69 & 1.85 & 1.90 \\
\hline
\end{tabular}

anaerobic spore formers count affects the shelf life of roast beef, also the storage temperature is important to extend the shelf life of roast beef.

In refrigerated treatment, clostridium counts were lower than those kept at abused temperature, and there was an increase in its population at the lower nitrite levels. The decrease in inhibition observed in the present research appears to be related to the decline in residual nitrite [38] [39]. Antimicrobial effect of nitrite may attribute to the action of nitric oxide or nitrous acid that is toxic for some bacteria especially Gram-positive such as Clostridium botulinum, this effect depends on the interaction with many other factors such as ingoing nitrite level, residual nitrite level and presence of other additives like ascorbate [40]. This brings to conclusion that refrigeration is essential to lower the anaerobic spore formers count whether at high or low nitrite level.

However, significant concerns exist because nitrite may react with amines and amino acids to produce $N$-nitrosamines, which are known to be a potential carcinogenic and mutagenic [41]. However, when the added nitrite concentration is within the legal legislations we expect that it will not be hazardous to human health. [42] mentioned that the information of nitrite toxicity denoted that the fatal dose of sodium nitrite was in the range of $22-23 \mathrm{mg} / \mathrm{kg}$ body weight.

Moreover, there has been a growing interest in natural ingredients to be used in food and food products as 
preservatives instead of synthetic chemicals that may cause health hazards, because natural ingredients have greater application for increasing consumer acceptability, palatability, stability and shelf-life of food products. Consequently, search for natural additives, especially of plant origin, has notably increased in recent years [43]. Most of these researches failed to find complete alternatives but others succeeded in partial replacement of nitrite with natural agents. [44] found that the ability to substitute $50 \%$ of the used nitrite in mortadella stored at $5^{\circ} \mathrm{C}$ when using combinations of $60 \mathrm{ppm}$ nitrite with $240 \mathrm{mg}$ OLE/100g meat.

\section{Conclusion}

It could be concluded from the overall results that the added nitrite concentration and chilling temperature had significant effect on the chemical, microbiological and shelf life of roast beef. Abused storage temperature limits the shelf life of roast beef, and the storage under refrigeration $\left(4^{\circ} \mathrm{C}\right)$ extends the shelf life of roast beef. The increased addition of nitrite alone up to $0.018 \%$, without good refrigeration practice $\left(4^{\circ} \mathrm{C}\right)$, also limits the shelf life of roast beef. Addition of $0.026 \%$ nitrite with proper refrigeration has resulted in an extension of the roast beef shelf life.

\section{Acknowledgements}

Our deepest thanks are to the employees of the Department of Nutrition and Food Science for their help and support.

\section{References}

[1] Toldr, F. and Reig, M. (2011) Innovations for Healthier Processed Meats. Trends in Food Science and Technology, 22, 517-522. http://dx.doi.org/10.1016/j.tifs.2011.08.007

[2] Marco, A., Navarro, L. and Flores, M. (2006) The Influence of Nitrite and Nitrate on Microbial, Chemical and Sensory Parameters of Slow Dry Fermented Sausage. Meat Science, 73, 660-673. http://dx.doi.org/10.1016/j.meatsci.2006.03.011

[3] Honikel, K. (2008) The Use and Control of Nitrate and Nitrite for the Processing of Meat Products. Meat Science, 78, 68-76. http://dx.doi.org/10.1016/j.meatsci.2007.05.030

[4] Cassens, R.G. (1997) Residual Nitrite in Cured Meat. Food Technology, 51, 53-55.

[5] HotchKiss, J.H. and Cassens. R.G. (1987) Nitrate, Nitrite, and Nitroso Compounds in Foods. IFT Scientific Status Summary by the Institution of Food Technologists, Chicago.

[6] Varnam, A.H. and Sutherland, J.P. (1995) Meat and Meat Products. Chapman and Hall, London.

[7] Pegg, R. and Shahid, F. (1997) Unraveling the Chemical Identity of Meat Pigment. CRC Critical Reviews in Food Science and Nutrition, 37, 561-589. http://dx.doi.org/10.1080/10408399709527789

[8] Goutefongea, R. (1992) Salting and Curing. In: Girard, J.P., Ed., Technology of Meat and Meat Products, Ellis Wormwood, New York, 1115-1320.

[9] Man, C. and Jones, A. (1994) Shelf Life Evaluation of Foods. Chapman and Hall, London. http://dx.doi.org/10.1007/978-1-4615-2095-5

[10] Ham Processing (2004) In Meat Processing. WATT Publishing, Rockford.

[11] Eber, M. and Muller, W. (1999) Studies on the Suitability of Hampshire Type Meat for Processing Cooked Ham. Fleischwiritschaft International, 1, 19-22.

[12] Fessmann, K. (1996) Smoking Technology at a Time of Change. Fleischwiritschaft International, 75, 32-34.

[13] Berg, H. and Kolar, K. (1991) Evaluation of Rapid Moisture, Fat, Protein and Hydroxyl Proline Determination in Beef and Pork Using the Infratech Food and Feed Analyzer. Fleischwirtschaft International, 71, 787-789.

[14] AOAC (1995) Official Methods of Analysis. 16th Edition, Association of Official Analytical Chemists, Washington DC.

[15] Kirk, R. and Sawyer, R. (1991) Pearson's Composition and Analysis of Food. 9th Edition, Longman Scientific and Technical, Essex.

[16] Faustman, C., Yin, M.C. and Nadeau, D.B. (1992) Color Stability, Lipid Stability, and Nutrient Composition of Red and White Veal. Journal of Food Science, 57, 302-304. http://dx.doi.org/10.1111/j.1365-2621.1992.tb05481.x

[17] Cheah, P.B. and Hasim, N.H. (2000) Natural Antioxidant Extract from Galangal for Minced Beef. Journal of Food and Agriculture, 80, 1565-1571. http://dx.doi.org/10.1002/1097-0010(200008)80:10<1565::AID-JSFA677>3.0.CO;2-7 
[18] Cook, R.L. (1991) Microbial Methods for the Meat Industry. 2nd Edition, Meat Industry Research Institute, Hamilton.

[19] Littell, R.C., Freund, R.J. and Spector, P.C. (1991) SAS System for Linear Model. 8th Edition, SAS Institute Inc, Cary.

[20] SAS Institute (2007) SAS User’s Guide in Statistics. 9th Edition, SAS Institute, Inc., Cary.

[21] Abdullah, B.M. (2004) Beef and Sheep Mortadella: Formulation, Processing and Quality Aspects. International Journal of Food Science and Technology, 39, 177-182. http://dx.doi.org/10.1046/j.0950-5423.2003.00763.x

[22] Ray, B. (2001) Fundamental Food Microbiology. 2nd Edition, CRC Press, New York.

[23] Kilic, B., Cassens, R. and Borchert, L. (2002) Effect of Turkey Meat, Phosphate, Sodium Lactate, Carrageenan, and Konjac on Residual Nitrite in Cured Meats. Journal of Food Science, 67, 29-31. http://dx.doi.org/10.1111/j.1365-2621.2002.tb11353.x

[24] Larsen, J.E., Macneil, J.H. and Mast, M.G. (1986) Sensory and Quality Characteristics of Poultry Frankfurters Containing Nitrite and Sorbate. Poultry Science, 65, 1542-1546. http://dx.doi.org/10.3382/ps.0651542

[25] Vossen, E., Doolaege, E., Moges, H., Meulenaer, B., Szczepaniak, S., Raes, K. and Smet, S. (2012) Effect of Sodium Ascorbate Dose on the Shelf Life Stability of Reduced Nitrite Liver Pâtés. Meat Science, 91, 29-35. http://dx.doi.org/10.1016/j.meatsci.2011.12.001

[26] Kanner, J. (1994) Oxidative Process in Meat Products: Quality Implication. Meat Science, 36, 169-189. http://dx.doi.org/10.1016/0309-1740(94)90040-X

[27] Shahidi, F. and Zhong, Y. (2010) Lipid Oxidation and Improving the Oxidative Stability. Chemical Society Reviews, 39, 4067-4079. http://dx.doi.org/10.1039/b922183m

[28] Freybler, L.A., Gray, J., Asghar, A., Booren, A.M., Pearson, A.M. and Buckley, D.J. (1993) Nitrite Stabilization of Lipids in Cured Pork. Meat Science, 33, 85-96. http://dx.doi.org/10.1016/0309-1740(93)90096-Z

[29] Moarefiann, M., Barzegar, M., Sattari, M. and Naghdi Badi, H. (2012) Production of Functional Cooked Sausage by Mentha piperita Essential Oil as a Natural Antioxidant and Antimicrobial Material. Journal of Medicinal Plants, 11, 46-57.

[30] Riettel, J.M., Vanlaak and Frans, J.M. (1991) Microbiological Condition of Restructed Steaks Prepared from Pre and Post Rigor Beef. Journal of Food Protection, 54, 357-359.

[31] Roberts, D., Hoober, W. and Greenwood, M. (1996) Practical Food Microbiology. Public Health Laboratory, London.

[32] Shapton, D.A. and Shapton, N.F. (1998) Principles and Practices for the Safe Processing of Foods. Wood Head Publishing Ltd., Cambridge.

[33] Cutter, C.N. (2002) Microbial Control by Packaging: A Review. Critical Review in Food Science and Nutrition, 42, 151-161. http://dx.doi.org/10.1080/10408690290825493

[34] Davies, A. and Board, R. (1998) The Microbiology of Meat and Poultry. Blackie Academic and Professional, London.

[35] Jay, J.M. (1992) Modern Food Microbiology. 4th Edition, Van Nostrand Reinhold, New York. http://dx.doi.org/10.1007/978-94-011-6480-1

[36] Lawrie, R. (1988) Development in Meat Science-4. Elsevier Applied Science, London.

[37] Freixanet, L. (2004) Additives and Ingredients in Ham Production. Meat Processing Global, 16-22.

[38] Tompkin, R.B., Christlansen, L.N. and Shaparis, A.B. (1978) Effect of Prior Refrigeration on Botulinal out Growth in Perishable Canned Cured Meat When Temperature Abused. Applied and Environmental Microbiology, 35, 863-866.

[39] Sanabria, C., Carrascose, A., Sabio, E. and Fallola, A. (1997) HACCP for “Iberico” Dry-Cured Ham. Die Fleischwirtschaft, 77, 1006-1008.

[40] Sindelar, J. and Milkowski, A. (2011) Sodium Nitrite in Processed Meat and Poultry Meats: A Review of Curing and Examining the Risk/Benefit of Its Use. American Meat Science Association White Paper Series No. 3, 1-14.

[41] Byun, M., Ahn, H., Kim, J. and Lee, J. (2004) Determination of Volatile N-Nitrosamines in Irradiated Fermented Sausage by Gas Chromatography Coupled to a Thermal Energy Analyzer. Journal of Chromatography A, 1054, 403-407. http://dx.doi.org/10.1016/S0021-9673(04)01302-0

[42] Epley, R., Addis, P. and Warthesen, J. (1992) Nitrite in Meat. Minnesota Extension Service, University of Minnesota, St. Paul. http://conservancy.umn.edu/bitstream/handle/11299/50792/00974.pdf?sequence=1

[43] Naveena, B., Sen, A., Vaithiyanathan, S., Babji, Y. and Kondaiah, N. (2008) Comparative Efficacy of Pomegranate Juice, Pomegranate Rind Powder Extract and BHT as Antioxidants in Cooked Chicken Patties. Meat Science, 80, 13041308. http://dx.doi.org/10.1016/j.meatsci.2008.06.005

[44] Al Marazeeq, K., Haddadin, M., Al Abdullah, B. and Angor, M. (2015) Effect of Nitrite Substitution with Olive Leaves Extract on Color and Sensory Properties of Beef Mortadella. Journal of Agricultural Science, 7, 1-9. http://dx.doi.org/10.5539/jas.v7n12p120 